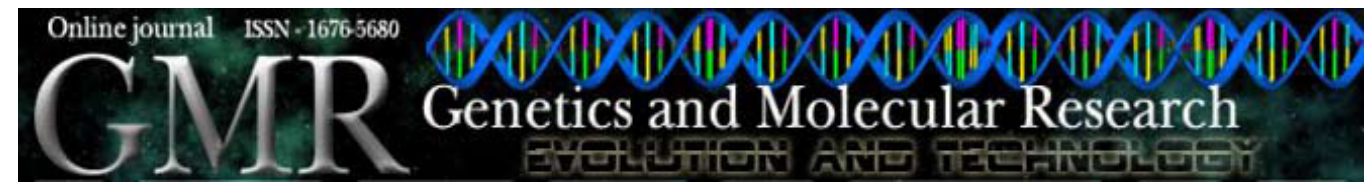

\title{
Genetic relationships among Heliconia (Heliconiaceae) species based on RAPD markers
}

\author{
L.P. Marouelli' ${ }^{1}$ P.W. Inglis ${ }^{2}$, M.A. Ferreira ${ }^{2}$ and G.S.C. Buso ${ }^{2}$ \\ ${ }^{1}$ Departamento de Botânica, Universidade de Brasília, Brasília, DF, Brasil \\ ${ }^{2}$ Embrapa Recursos Genéticos e Biotecnologia, Brasília, DF, Brasil \\ Corresponding author: G.S.C. Buso \\ E-mail: buso@cenargen.embrapa.br
}

Genet. Mol. Res. 9 (3): 1377-1387 (2010)

Received March 20, 2010

Accepted May 15, 2010

Published July 13, 2010

DOI 10.4238/vol9-3gmr847

ABSTRACT. The family Heliconiaceae contains a single genus, Heliconia, with approximately 180 species of Neotropical origin. This genus was formerly allocated to the family Musaceae, but today forms its own family, in the order Zingiberales. The combination of inverted flowers, a single staminode and drupe fruits is an exclusive characteristic of Heliconia. Heliconias are cultivated as ornamental garden plants, and are of increasing importance as cut flowers. However, there are taxonomic confusions and uncertainties about the number of species and the relationships among them. Molecular studies are therefore necessary for better understanding of the species boundaries of these plants. We examined the genetic variability and the phylogenetic relationships of 124 accessions of the genus Heliconia based on RAPD markers. Phenetic and cladistic analyses, using 231 polymorphic RAPD markers, demonstrated that the genus Heliconia is monophyletic. Groupings corresponding to currently recognized species and some subgenera were found, and cultivars and hybrids were found to cluster with their parents. RAPD analysis generally agreed with morphological species classification, except for the position of the subgenus Stenochlamys, which was found to be polyphyletic.

Key words: Genetic variability; Heliconia; RAPD; Molecular marker; Phylogenetic relationships; Zingiberales 


\section{INTRODUCTION}

The Heliconiaceae family contains a single genus, Heliconia L., with approximately 200 to 250 species of Neotropical origin, ranging from north Mexico to the south of Brazil. Only a small paleotropical group, with approximately six species, is endemic to the Pacific Islands (Berry and Kress, 1991; Andersson, 1998). In Brazil, there are about 40 species distributed in two main areas, the Amazon Basin and the Atlantic Forest, which correspond to the primary areas of the distribution of the genus in the country (Kress, 1990).

Originally, heliconias were included in the family Musaceae, but the genus was always considered to be homogeneous and with its own characteristics, such as inverted flowers, the presence of a single staminode and drupe-type fruits. Nakai (1941) raised Heliconia to the family level (Heliconiaceae), and today, this family has only one genus (Heliconia), belonging to the order Zingiberales, which comprises eight families: Musaceae (bananas), Strelitziaceae (the birds of paradise), Lowiaceae (no common name), Heliconiaceae (heliconias), Zingiberaceae (the gingers), Costaceae (the costus), Cannaceae (the cannas), and Marantaceae (the prayer plants) (Berry and Kress, 1991).

Heliconias are herbaceous erect perennial plants, with simpodial rhizomes (Cronquist, 1981), and possess a pseudocaule formed by the juxtaposition of the petioles or leaf laminas, with heights varying from less than 1 to $7 \mathrm{~m}$, depending on the species (Dahlgren et al., 1985). The leaves are distichous, with a long basal sheath and a long and expanded petiole (Cronquist, 1981).

The inflorescence is terminal, erect or pendant, composed of bracts in one plane (distichous) or spirally arranged. Each bract constitutes and involves one cincinnus with many flowers. The bracts are modified leaves, cymbiform or lanceolate-conduplicated, with variable coloration, size, arrangement, texture, and number, and some of these characteristics are used in the subgenus classification (Cronquist, 1981; Berry and Kress, 1991; Andersson, 1992). Nowadays, heliconias may be subdivided into five subgenera: Taeniostrobus (Kuntze) Griggs; Heliconia (Andersson, 1981, 1985, 1992); Stenochlamys Baker; Griggsia L. Anderss., and Heliconiopsis (Miq.) Kress, which contains the Pacific Islands species.

The genus Heliconia L. contains a great diversity of species, varieties, hybrids, and cultivars of ornamental and commercial interest. However, there is confusion and uncertainty about the number of species and the relationships among them. Therefore, molecular studies may help to increase our understanding of the genetic variability in the genus and its speciation process.

RAPD (random amplified polymorphic DNA) (Williams et al., 1990) markers have been applied in genetic variability studies of many plants, such as in tree species (Ciampi and Magalhães, 2001), Oryza (Buso et al., 1998) and Capsicum (Buso et al., 2003). RAPD markers were also shown to be a powerful tool for genetic variability studies and clarification of the relationship between Heliconia species (Kumar et al., 1998). The objective of the present study was to use RAPD markers to further analyze the genetic variability and phylogenetic relationships among Heliconia species, cultivars and hybrids.

\section{MATERIAL AND METHODS}

One hundred and twenty-four accessions were analyzed, composed of 119 Heliconia species, cultivars and hybrids (Table 1) and five accessions from other genera of the order Zingiberales (Table 2), which were used to root the dendrograms. DNA was extracted from fresh leaves using a CTAB protocol (Doyle and Doyle, 1987), quantified on agarose gels, and diluted to a final concentration of approximately $3.0 \mathrm{ng} / \mu \mathrm{L}$. One hundred and fifty different 10-mer RAPD primers (Operon Technologies Inc.) were screened for DNA amplification and polymorphic fragment quantity and quality. The markers were selected based on their polymorphism and robustness. 
Table 1. List of the 119 accessions of Heliconia and reference to the materials deposited in the Brasília University Herbarium.

\begin{tabular}{|c|c|}
\hline Taxons & Voucher specimens \\
\hline \multirow{2}{*}{\multicolumn{2}{|c|}{$\begin{array}{l}\text { Subgenus Heliconia } \\
\text { Hepiscopalis Vell. }\end{array}$}} \\
\hline \multirow{2}{*}{\multicolumn{2}{|c|}{ H. bihai (L.) L. }} \\
\hline & \\
\hline \multicolumn{2}{|l|}{ H. bihai (L.) L. } \\
\hline H. bihai (L.) L. cv. Banana Split & Marouelli, L.P. 7 (UB) \\
\hline \multicolumn{2}{|l|}{ H. bihai (L.) L. cv. Nappi Yellow } \\
\hline \multirow{2}{*}{\multicolumn{2}{|c|}{$\begin{array}{l}\text { H. bihai (L.) L. cv. Nappi Yellow } \\
\text { H. bihai (L.) L. cv. Lobster Claw Two }\end{array}$}} \\
\hline & \\
\hline H. bihai (L.) L. cv. Lobster Claw Two & Marouelli, L.P. 3 (UB) \\
\hline H. bihai (L.) L. cv. Orange Peachy & Marouelli, L.P. 33 (UB) \\
\hline \multicolumn{2}{|l|}{ H. bihai (L.) L. (Terra do Meio) } \\
\hline H. bihai (L.) L. cv. Kamehameha & Marouelli, L.P. 47 (UB) \\
\hline \multicolumn{2}{|l|}{ H. bihai (L.) L. cv. Emerald Forest } \\
\hline H. bourgaeana Petersen & Marouelli, L.P. 25 (UB) \\
\hline \multicolumn{2}{|l|}{ H. caribea Lamarck } \\
\hline \multicolumn{2}{|l|}{ H. caribea Lamarck } \\
\hline H. caribea Lamarck & Marouelli, L.P. 35 (UB) \\
\hline \multicolumn{2}{|l|}{ H. champneiana Griggs } \\
\hline \multicolumn{2}{|l|}{ H. champneiana Griggs cv. Splash } \\
\hline \multicolumn{2}{|l|}{$\begin{array}{l}\text { H. orthotricha L. Anderss. cv. Eclipse Total } \\
\text { L }\end{array}$} \\
\hline H. orthotricha L. Anderss. cv. Eclipse Total & Marouelli, L.P. 48 (UB) \\
\hline \multicolumn{2}{|l|}{$\begin{array}{l}\text { H. stricta Huber } \\
\text { P. cv. Echpse lotal }\end{array}$} \\
\hline \multicolumn{2}{|l|}{ H. stricta Huber cv. Dwarf Jamaica } \\
\hline \multirow{2}{*}{\multicolumn{2}{|c|}{$\begin{array}{l}\text { H. stricta Huber cv. Dwarf Jamaica } \\
\text { H. stricta Huber cv. Fire Bird }\end{array}$}} \\
\hline & \\
\hline H. stricta Huber cv. Tagami & Marouelli, L.P. 27 (UB) \\
\hline \multicolumn{2}{|l|}{$\begin{array}{l}\text { H. stricta Huber cv. Tagami } \\
\text { H. stricta Huber cv. Tagami }\end{array}$} \\
\hline \multicolumn{2}{|l|}{ H. stricta Huber cv. Dorado Gold } \\
\hline H. stricta Huber cv. Dorado Gold & Marouelli, L.P. 20 (UB) \\
\hline H. stricta Huber cv. Olivera's Sharonii & Marouelli, L.P. 18 (UB) \\
\hline H. stricta Huber cv. Iris Red & Marouelli, L.P. 23 (UB) \\
\hline H. stricta Huber cv. Las Cruces & Marouelli, L.P. 32 (UB) \\
\hline H. stricta Huber cv. Bucky & Marouelli, L.P. 45 (UB) \\
\hline H. wagneriana Petersen & \\
\hline H. latispatha Bentham cv. Orange Gyro & \\
\hline H. latispatha Bentham cv. Orange Gyro & Marouelli, L.P. 39 (UB) \\
\hline H. latispatha Bentham & \\
\hline H. latispatha Bentham & Marouelli, L.P. 40 (UB) \\
\hline H. spathocircinata Aristeg. & \\
\hline H. spathocircinata Aristeg. & \\
\hline H. farinosa Raddi & \\
\hline H. rivularis Emygdio \& Santos & \\
\hline H. rivularis Emygdio \& Santos & Marouelli, L.P. 9 (UB) \\
\hline H. sampaioana L. Emygdio & \\
\hline H. velloziana L. Emygdio & \\
\hline H. velloziana $\mathrm{L}$. Emygdio & Marouelli, L.P. 16 (UB) \\
\hline Subgenus Stenochlamys Baker & \\
\hline H. acuminata L. C. Richard & \\
\hline H. angusta Vellozo & \\
\hline H. angusta Vellozo cv. Holiday & Marouelli, L.P. 28 (UB) \\
\hline H. angusta Vellozo cv. Yellow Christmas & Marouelli, L.P. 29 (UB) \\
\hline H. angusta Vellozo cv. Orange Christmas & Marouelli, L.P. 30 (UB) \\
\hline H. laneana Barreiros var. Flava & \\
\hline H. laneana Barreiros & \\
\hline H. lacletteana L. Em. et. Em. Santos & \\
\hline H. lingulata Ruiz \& Pavón & Marouelli, L.P. 42 (UB) \\
\hline H. lingulata Ruiz \& Pavón & \\
\hline H. lingulata Ruiz \& Pavón cv. Fan & \\
\hline H. pseudoaemygdiana L. Emygdio \& E. Santos & Marouelli, L.P. 36 (UB) \\
\hline H. psittacorum L. f. cv. Sassy & \\
\hline H. psittacorum L. f. cv. Sassy & Marouelli, L.P. 12 (UB) \\
\hline
\end{tabular}




\section{Table 1. Continued.}

\begin{tabular}{|c|c|}
\hline Taxons & Voucher specimens \\
\hline \multicolumn{2}{|l|}{ H. psittacorum L. f. cv. Choconiana } \\
\hline H. psittacorum L. f. cv. St. Vincent Red & Marouelli, L.P. 14 (UB) \\
\hline \multicolumn{2}{|l|}{ H. psittacorum L. f. cv. St. Vincent Red } \\
\hline \multicolumn{2}{|l|}{ H. psittacorum L. f. cv. St. Vincent Red } \\
\hline H. psittacorum L. f. cv. Flamingo & Marouelli, L.P. 46 (UB) \\
\hline \multicolumn{2}{|l|}{ H. richardiana Miquel } \\
\hline H. densiflora $\mathrm{cv}$. Fire flash & Marouelli, L.P. 13 (UB) \\
\hline \multicolumn{2}{|l|}{ H. metallica Planchon \& Linden ex Hooker } \\
\hline H. metallica Planchon \& Linden ex Hooker & Marouelli, L.P. 19 (UB) \\
\hline H. subulata Andersson & Marouelli, L.P. 24 (UB) \\
\hline \multicolumn{2}{|l|}{ H. mathiasiae Daniels \& Stiles } \\
\hline \multicolumn{2}{|l|}{ H. hirsuta L. f. } \\
\hline H. hirsuta L. f. & Marouelli, L.P. 41 (UB) \\
\hline \multicolumn{2}{|l|}{ H. hirsuta L. f. cv. Burle Marx } \\
\hline \multicolumn{2}{|l|}{ H. hirsuta L. f. cv. Yellow Panama } \\
\hline \multicolumn{2}{|l|}{ H. hirsuta L. f. cv. Darrell } \\
\hline \multicolumn{2}{|l|}{ H. longiflora R.R. Smith } \\
\hline \multicolumn{2}{|l|}{ Subgenus Griggsia L. Anderss. } \\
\hline H. magnifica Kress & Marouelli, L.P. 4 (UB) \\
\hline \multicolumn{2}{|l|}{ H. pogonantha Cufodontes } \\
\hline H. pogonantha Cufodontes & Marouelli, L.P. 21 (UB) \\
\hline \multicolumn{2}{|l|}{ H. vellerigera Poepping } \\
\hline H. vellerigera Poepping & Marouelli, L.P. 5 (UB) \\
\hline \multicolumn{2}{|l|}{ H. mariae J.D. Hooker } \\
\hline \multicolumn{2}{|l|}{ H. chartacea Lane ex Barreiros } \\
\hline H. chartacea Lane ex Barreiros cv. Sexy Pink & \\
\hline H. chartacea Lane ex Barreiros cv. Sexy Pink & Marouelli, L.P. 17 (UB) \\
\hline H. chartacea Lane ex Barreiros cv. Sexy Scarlet & \\
\hline H. chartacea Lane ex Barreiros cv. Sexy Scarlet & Marouelli, L.P. 6 (UB) \\
\hline H. chartacea Lane ex Barreiros cv. Sexy Orange & \\
\hline H. chartacea Lane ex Barreiros cv. Amazonita & \\
\hline H. collinsiana Griggs & \\
\hline H. collinsiana Griggs & \\
\hline H. collinsiana Griggs & Marouelli, L.P. 11 (UB) \\
\hline H. pendula Wawra & \\
\hline H. pendula Wawra & Marouelli, L.P. 8 (UB) \\
\hline H. platystachys Baker & \\
\hline H. juruana Loes & \\
\hline H. marginata (Griggs) Pittier & \\
\hline H. marginata (Griggs) Pittier cv. Nutea & \\
\hline H. rauliniana Barreiros & \\
\hline H. rauliniana Barreiros & Marouelli, L.P. 38 (UB) \\
\hline H. rostrata Ruiz \& Pavón & \\
\hline H. rostrata Ruiz \& Pavón & \\
\hline H. rostrata Ruiz \& Pavón & \\
\hline H. rostrata Ruiz \& Pavón & Marouelli, L.P. 43 (UB) \\
\hline H. standleyi Macbride & \\
\hline H. nariniensis Abalo \& G. L. Morales & \\
\hline Not included in revisions of the genus & \\
\hline H. santaremensis & \\
\hline Hybrids & \\
\hline H. episcopalis Vell. x H. spathocircinata Aristeg. cv. Mantenensis & \\
\hline H. caribea Lamarck x H. bihai (L.) L. cv. Jacquinii & \\
\hline H. caribea Lamarck x H. bihai (L.) L. cv. Jacquinii & Marouelli, L.P. 2 (UB) \\
\hline H. caribea Lamarck x H. bihai (L.) L. cv. Richmond Red & \\
\hline H. caribea Lamarck x H. bihai (L.) L. cv. Richmond Red & Marouelli, L.P. 34 (UB) \\
\hline H. psittacorum L. f. x H. spathocircinata Aristeg. cv. Red Opal & \\
\hline H. psittacorum L. f. x H. spathocircinata Aristeg. cv. Fire Opal & \\
\hline H. psittacorum L. f. x H. spathocircinata Aristeg. cv. Alan Carle & \\
\hline H. psittacorum L. f. x H. spathocircinata Aristeg. cv. Golden Torch & \\
\hline H. psittacorum L. f. x H. spathocircinata Aristeg. cv. Golden Torch & Marouelli, L.P. 10 (UB) \\
\hline H. $\mathrm{x}$ Nickeriensis Maas \& deRooij (H. marginata $\mathrm{x}$ H. psittacorum) & Marouelli, L.P. 22 (UB) \\
\hline H. x episcopalis Vell. & \\
\hline
\end{tabular}


Table 2. Outgroup accessions representing five families of the order Zingiberales.

\begin{tabular}{ll}
\hline Species & Family \\
\hline Musa coccinea Andr. & Musaceae \\
Costus barbatus Susseng. & Costaceae \\
Alpinia purpurata (Vieill.) Schum. & Zingiberaceae \\
Ischnosiphon ovatus Koern. & Marantaceae \\
Phenakospermum guyannense (L. C. Rich.) Endl. Ex Miq. & Strelitziaceae \\
\hline
\end{tabular}

Each polymerase chain reaction (PCR) mixture was composed of the following components: $0.2 \mu \mathrm{g} / \mathrm{mL}$ bovine serum albumin; $0.2 \mathrm{mM}$ each dNTP; $0.4 \mu \mathrm{M}$ primer; $1 \mathrm{U}$ Taq polymerase; $7.5 \mathrm{ng}$ DNA; $3.42 \mu \mathrm{L}$ ultra-pure sterile water, and 1X Taq DNA polymerase buffer (10 $\mathrm{mM}$ Tris- $\mathrm{HCl}, \mathrm{pH} 8.3,50 \mathrm{mM} \mathrm{KCl}, 1.5 \mathrm{mM} \mathrm{MgCl}$ ). PCR-cycling conditions were 40 cycles of DNA denaturation at $92^{\circ} \mathrm{C}$ for $1 \mathrm{~min}$, primer annealing at $35^{\circ} \mathrm{C}$ for $1 \mathrm{~min}$ and extension at $72^{\circ} \mathrm{C}$ for $2 \mathrm{~min}$, with a final incubation at $72^{\circ} \mathrm{C}$ for $7 \mathrm{~min}$ following cycling. The PCR products were visualized after electrophoresis on $1.5 \%$ agarose gels containing ethidium bromide and including 1-kb DNA ladders. The DNA patterns were scored as 1 for presence and 0 for absence of a band, yielding a binary matrix.

For phenetic analysis, the data were used to construct a genetic similarity matrix employing the Jaccard coefficient. A dendrogram was constructed using UPGMA (unweighted pair group method with arithmetic mean), implemented in NTSYS-PC, version 2.02 (Rohlf, 1993) and the cophenetic correlation coefficient calculated using the Mantel test. Non-parametric bootstrap analysis with 1000 random samplings, using BOOD v. 3.0 (Coelho, 2001), was done to assess group support, where bootstrap values above $95 \%$ were considered to be highly significant, values between $94-70 \%$ were considered to be moderate and values between $69-51 \%$ were considered to be weakly supported. However, if the moderate or weak values are repeated in many analyses with different markers, they may indicate support for the group (Hillis and Bull, 1993; Li, 1997).

The cladistic analysis was performed under the maximum parsimony criterion using PAUP 4.0b10 (Swofford, 2002), considering each character as equally weighted and unordered. Heuristic searches were performed using random taxon addition, tree bisection-reconnection branch swapping and ACCTRAN character optimization. Bootstrap analysis was used to assess the degree of support for each branch, and tree statistics such as consistency index (Kluge and Farris, 1969) and retention index (Farris, 1989) were computed.

\section{RESULTS AND DISCUSSION}

Fourteen primers were selected (OPA-13, OPA-20, OPB-5, OPB-11, OPC-2, OPD-7, OPE-9, OPF-5, OPG-9, OPO-14, OPP-3, OPV-16, OPV-18, and OPX-18) from the screening of 150 primers. The selected primers produced a high degree of polymorphism, where of a total of 374 amplified bands, 231 were polymorphic (Table 3), with each primer giving a mean of 16.5 polymorphic bands. This high polymorphism may be related to the diversity of species and families included in this study (Figure 1).

In the phenetic analysis, the cophenetic correlation coefficient (Mantel test) revealed a good fit between the calculated distances graphically presented and the similarity matrix, with a value of $r=0.89$ for the dendrogram, where according to Sokal and Rohlf (1962), values of cophenetic correlation above 0.80 are preferable. The combination of the 231 
Table 3. Primer names, primer sequence and number of polymorphic bands produced by the 14 primers selected for the RAPD study of Heliconia accessions.

\begin{tabular}{llr}
\hline Primer & Sequence (5'- 3') & Polymorphic bands \\
\hline OPA-13 & CAG CAC CCA C & 15 \\
OPA-20 & GTT GCG ATC C & 24 \\
OPB-5 & TGC GCC CTT C & 18 \\
OPB-11 & GTA GAC CCG T & 20 \\
OPC-2 & GTG AGG CGT C & 20 \\
OPD-7 & TTG GCA CGG G & 13 \\
OPE-9 & CTT CAC CCG A & 20 \\
OPF-5 & CCG AAT TCC C & 12 \\
OPG-9 & CTG ACG TCA C & 15 \\
OPO-14 & AGC ATG GCT C & 13 \\
OPP-3 & CTG ATA CGC C & 6 \\
OPV-16 & ACA CCC CAC A & 14 \\
OPV-18 & TGG TGG CGT T & 23 \\
OPX-18 & TGG CAA GGC A & 18 \\
\hline
\end{tabular}

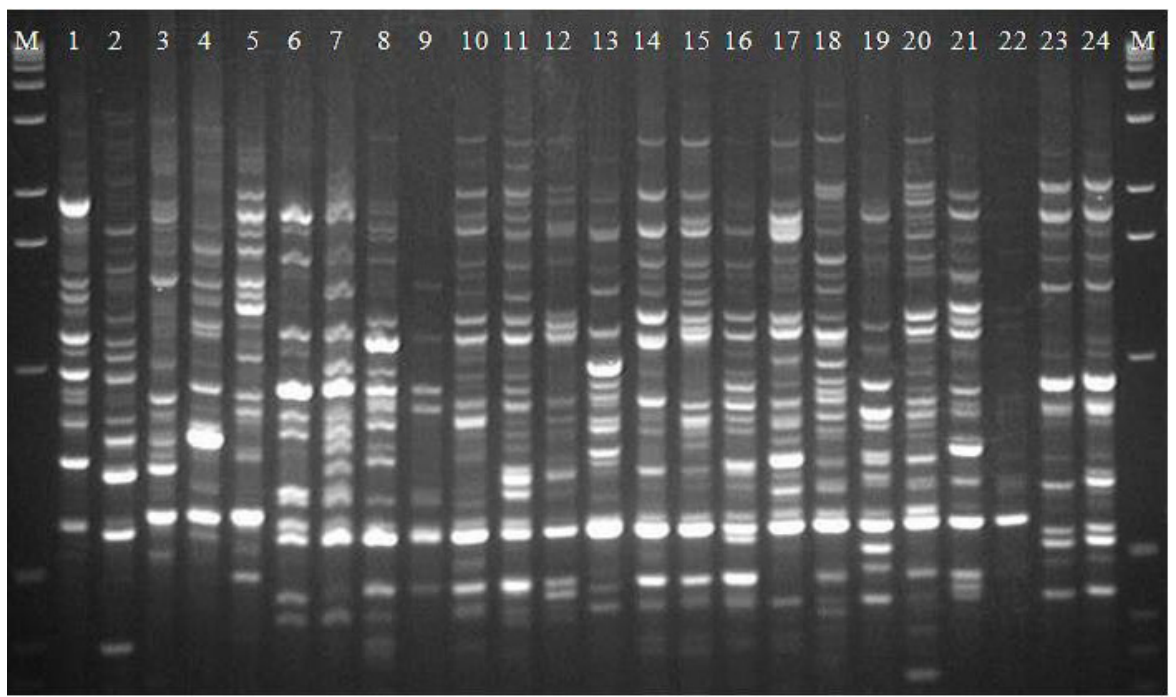

Figure 1. PCR banding pattern of Heliconia accessions and outgroup species revealed by RAPD markers on $1 \%$ agarose gels: amplification using primer OPA-20. $\mathrm{M}=1$-kb ladder (Invitrogen). Lanes 1-5 = outgroup species and lanes 6-24= Heliconia accessions.

polymorphic markers strongly supported the monophyly of Heliconia, with a bootstrap value of $100 \%$ (Figure 2), in relation to the five outgroup accessions included in the analysis.

The heliconias were divided into a large group, consisting of more than $90 \%$ of all accessions, subdivided into two (Clade 2 and Clade 3), and a related group, containing $\mathrm{H}$. latispatha accessions (Clade 1 - bootstrap 99\%). Clade 2 was subdivided into four subgroups. The first subclade included $H$. psittacorum, $H$. densiflora, $H$. richardiana, and $H$. collinsiana accessions; a larger sister subclade comprised $H$. rostrata, H. juruana, $H$. standley, H. platystachys, $H$. marginata, and $H$. rauliniana accessions. A second subclade comprised $H$. magnifica, $H$. pogonantha, $H$. marginata, $H$. vellerigera accessions, and cultivars of $H$. chartacea (bootstrap 91\%). The third subclade included H. metallica, H. longiflora, H. mathiasiae, and cultivars of H. hirsuta (bootstrap 51\%). 


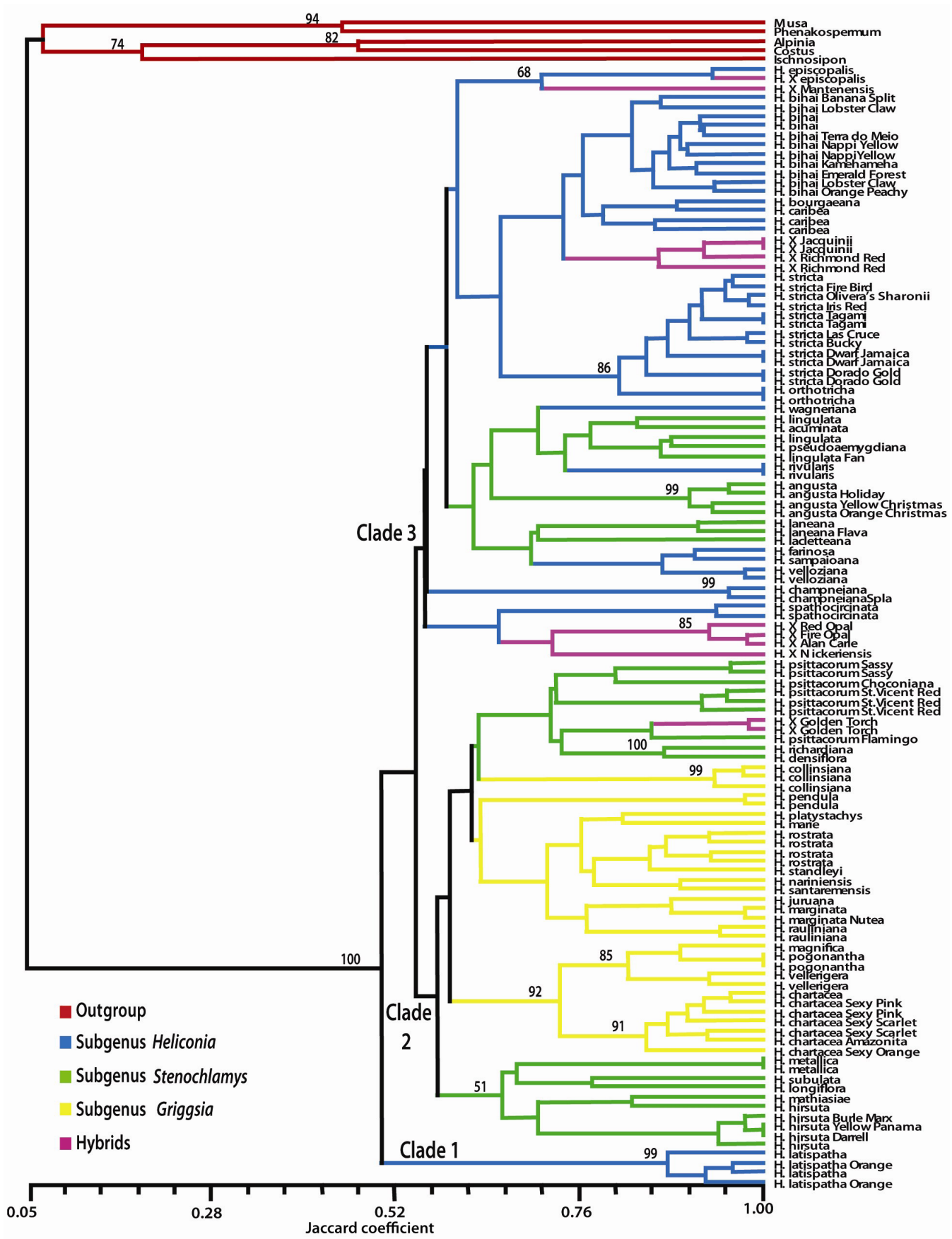

Figure 2. UPGMA dendrogram of the 124 accessions studied obtained by genetic similarity analysis using the Jaccard coefficient, generated by NTSYS-PC, with 231 RAPD markers. Bootstrap values $(>50 \%)$ are indicated above branches. The cophenetic correlation coefficient is 0.89 . 
Clade 3 possessed a more complex structure, where it was possible to identify four subclades. The first subclade was composed of a small grouping of $H$. episcopalis and its probable hybrids ( $H$. x mantenensis and $H$. x episcopalis) (bootstrap 68\%), a subgroup composed of $H$. bihai, $H$. bourgaeana, $H$. caribea accessions, and the hybrids of $H$. bihai x $H$. caribea (ex., $H$. bihai x $H$. caribea cv. Richmond Red), and a subgroup composed of cultivars of $H$. stricta and of $H$. orthotricha accessions (bootstrap 86\%). The second subclade comprised a grouping composed of $H$. lingulata, $H$. acuminata, $H$. pseudoaemygdiana, $H$. rivulares, $H$. angusta accessions (bootstrap 99\%), H. laneana, H. lacletteana, H. farinosa, H. sampaioana, and $H$. velloziana. The third and fourth sister subclades were composed of two $H$. champneiana accessions and a grouping comprising $H$. spathocircinata accessions and the hybrids $H$. psittacorum x H. spathocircinata cultivars Red Opal, Fire Opal and Alan Carle.

Of the conventional Heliconia subgenera, the subgenus Griggsia was monophyletic, with all assigned accessions being restricted to Clade 2. In addition, the subgenus Heliconia was, with the exception of $H$. latispatha, restricted to Clade 3. The subgenus Stenochlamys, however, was clearly polyphyletic in the analysis.

The maximum parsimony analysis of the data resulted in 2357 trees, from which was generated a strict consensus tree with 616 steps (Figure 3). All 231 polymorphic RAPD characters were considered to be informative for parsimony. This analysis showed a low consistency index (0.375), high homoplasy index (0.625), and generally low bootstrap support for the deeper branches. Nevertheless, it was possible to identify the Heliconiaceae family as a monophyletic group as suggested by previous studies (Kress et al., 2001; APG II, 2003; Kress and Specht, 2006). As in the phenetic analysis, the subgenus Griggsia was monophyletic. The subgenus Heliconia was also largely monophyletic, where, unlike in the phenetic analysis, H. latispatha grouped with other subgenus Griggsia accessions. However, an exception in the cladistic analysis was that $H$. farinosa, $H$. sampaioana, and $H$. velloziana grouped distantly from other Heliconia accessions. The species currently assigned to the subgenus Stenochlamys, H. psittacorum, H. densiflora, and $H$. lingulata were clearly allied to the other subgenus Griggsia species in our analysis. H. psittacorum, $H$. densiflora and $H$. richardiana are plants with erect inflorescences classified in the Stenochlamys subgenus, but are clearly closely related to the subgenus Griggsia, which includes species with generally pendant inflorescences (Andersson, 1985, 1992). This growth form is therefore phylogenetically misleading. Kress (1984) and Castro et al. (2007) earlier hypothesized that the section Griggsia is not monophyletic, as opposed to Andersson's hypothesis (1992). As in the phenetic analysis, the subgenus Stenochlamys was clearly polyphyletic.

In the phenetic and maximum parsimony analysis with RAPD markers, large groups composed of $H$. bihai, $H$. stricta, $H$. psittacorum, $H$. chartacea, $H$. angusta, and $H$. hirsuta cultivars and hybrids were observed, showing that in spite of these species having a large variety of forms (Berry and Kress, 1991), the cultivars show a high genetic similarity (Figures 2 and 3). The results also indicate that RAPD markers are extremely useful for the identification and assignment of unknown Heliconia cultivars to their species of origin. In this respect, the group composed of $H$. episcopalis and its probable hybrids ( $H$. x mantenensis and $H$. x episcopalis), by $H$. bihai, $H$. bourgaeana, and $H$. caribea accessions, and the hybrids of $H$. bihai $\mathrm{x} H$. caribea, by $H$. stricta cultivars and accessions of $H$. orthotricha, may be compared to the classification by Andersson (1992), which included these species in the subgenus Heliconia. Interestingly, the interspecific hybrids of the related species $H$. episcopalis and H. bihai grouped with one of their parentals. 


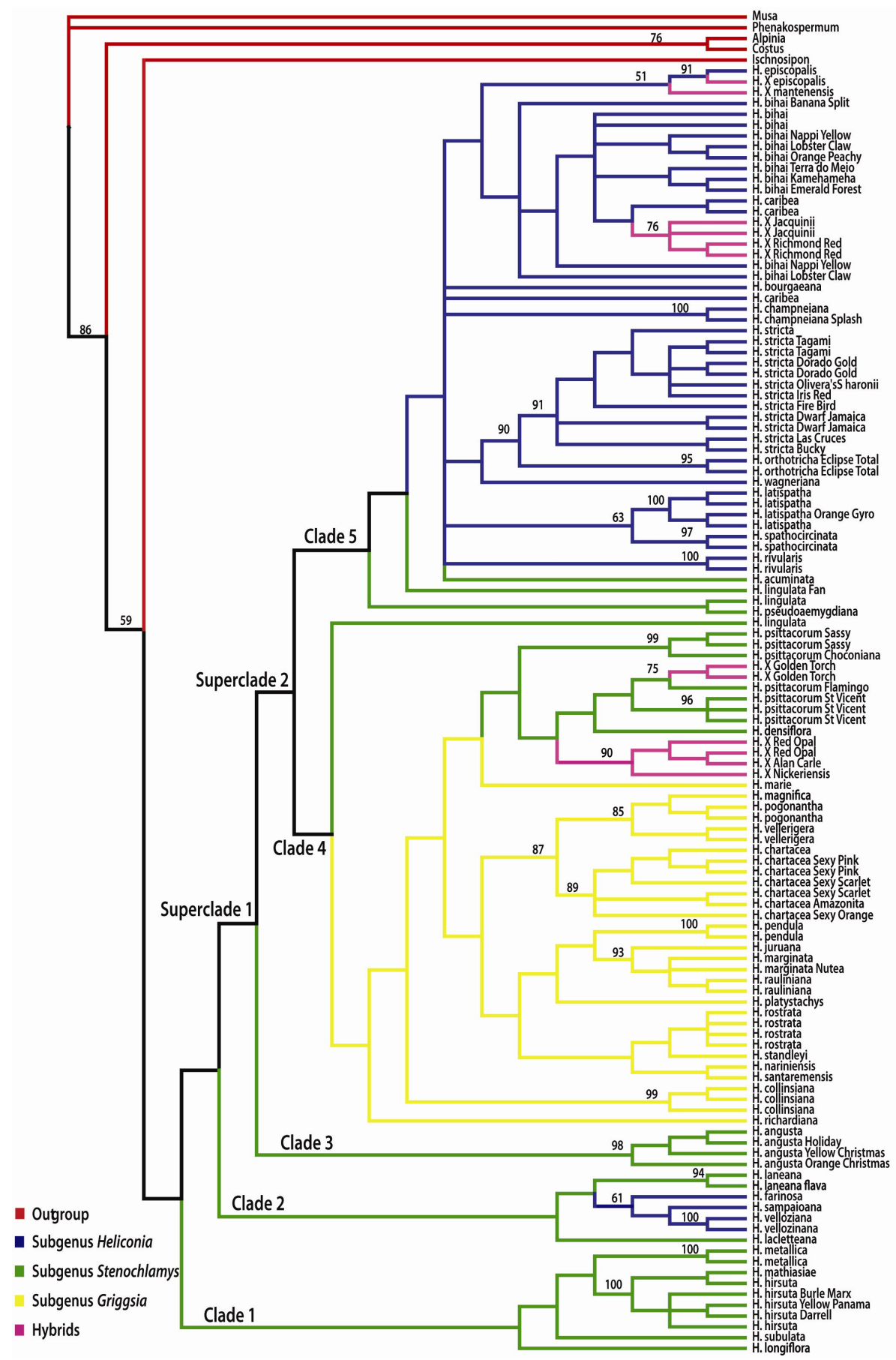

Figure 3. Strict consensus tree of 124 accessions obtained from maximum parsimony analysis calculated by PAUP* v.4, with 231 RAPD markers. Bootstrap values $(>50 \%)$ are indicated above branches. 
The group composed of $H$. lingulata, $H$. acuminata, $H$. pseudoaemygdiana and $H$. rivulares, $H$. angusta, $H$. laneana, $H$. lacletteana, $H$. farinosa, $H$. sampaioana and $H$. velloziana shares species from distinct subgenera. H. rivulares, $H$. farinosa, H. sampaioana, and $H$. velloziana are endemic to Brazil, and are classified in the section Farinosae of the subgenus Heliconia (Kress et al., 1993). H. lingulata, H. acuminata, H. pseudoaemygdiana, H. angusta, $H$. laneana, and $H$. lacletteana are from the same subgenus, but distinct sections.

H. lingulata and H. pseudoaemygdiana are from the section Lanea, and H. acuminata, $H$. angusta, H. laneana, and H. lacletteana are from the section Stenochlamys.

The subgroup of $H$. metallica, $H$. longiflora, $H$. mathiasiae, and $H$. hirsuta confirms the Andersson $(1985,1992)$ classification, which includes these species in the subgenus Stenochlamys, but in distinct sections.

H. metallica and H. mathiasiae are from the section Cannastrum, while H. longiflora and $H$. hirsute are from the section Zingiberastrum (Andersson, 1985).

In general, both analyses resulted in trees with similar topologies. However, differences in some internal groupings were observed: the group with $H$. latispatha cultivars were outliers in the phenetic analysis, but grouped with accessions of $H$. spathocircinata in the maximum parsimony analysis. The discrepancies between the analyses may have occurred due to the generally low clade support for deeper branches and/or to the fact that the phenetic analysis is based on a distance matrix (the character matrix is transformed into distance matrix), and parsimony (cladistic analysis) is based on character state (the characters are directly analyzed) (Schneider, 2003).

The data obtained with RAPD markers permitted a large genome coverage (Ferreira and Grattapaglia, 1998), and facilitated the identification of groups that corresponded well along species lines, where cultivars and hybrids clustered with their corresponding parents. The low bootstrap support for the more deeply branched clades and the incongruence in the relationships between some groups did not allow us to confidently reject the current division of Heliconia into its currently accepted subgenus and section assignments, as proposed by Andersson (1985, 1992), Kress et al. (1993) and Kress (1997). However, our data do give reason to doubt the current taxonomic structure of the genus, particularly in the position of the polyphyletic subgenus Stenochlamys. To extend these studies, DNA sequence-based analyses are required to further clarify the phylogenetic structure of Heliconia.

\section{ACKNOWLEDGMENTS}

The authors are grateful to CAPES for the scholarships received.

\section{REFERENCES}

Andersson L (1981). Revision of Heliconia sect. Heliconia (Musaceae). Nordic J. Bot. 1: 759-784.

Andersson L (1985). Revision of Heliconia subgen. Stenochlamys (Musaceae-Heliconioideae). Opera Bot. 82: 1-124.

Andersson L (1992). Revision of Heliconia subgen. Taeniostrobus and subgen. Heliconia (Musaceae - Heliconioideae). Opera Bot. 111: 1-98.

Andersson L (1998). Heliconiaceae. In: The Families and Genera of Vascular Plants. IV. Flowering Plants. Monocotyledons. Alismatanae and Commelinanae (except Gramineae) (Kubitzki K, ed.). Springer, Berlin, 226-230.

Angiosperm Phylogeny Group II (APG II) (2003). An update of the Angiosperm Phylogeny Group classification for the orders and families of flowering plants: APG II. Bot. J. Linn. Soc. 141: 399-436.

Berry F and Kress WJ (1991). Heliconia: An identification guide. Institution Press, Washington. 
Buso GSC, Rangel PH and Ferreira ME (1998). Analysis of genetic variability of South America wild rice populations (Oryza glumaepatula) with isozymes and RAPD markers. Mol. Ecol. 7: 107-117.

Buso GSC, Amaral ZPS, Bianchetti LB, Machado FR, et al. (2003). Genetic variability and phylogenetic analysis of Brazilian species of Capsicum. Capsicum Eggplant Newsl. 22: 13-16.

Castro CEF, May A and Gonçalves C (2007). Nomenclature review of species of genus Heliconia (Heliconiaceae). Rev. Bras. Hortic. Ornam. 13: 38-62.

Ciampi AY and Magalhães MTQ (2001). Análise da Variabilidade Genética de Três Espécies Arbóreas Utilizando Marcador Molecular RAPD. Comunicado Técnico 60. Embrapa-Cenargen, Brasília.

Coelho ASG (2001). BOOD: Avaliação de Dendrogramas Baseada em Estimativas de Distâncias/Similaridades Genéticas Através do Procedimento de Bootstrap. Versão 3.0. Universidade Federal de Goiás, Goiânia.

Cronquist A (1981). An Integrated System of Classification of Flowering Plants. Columbia University Press, New York.

Dahlgren RMT, Clifford HT and Yeo PF (1985). The Families of the Monocotyledons. Springer-Verlag, Berlin.

Doyle JJ and Doyle JL (1987). A rapid DNA isolation procedure from small quantities of fresh leaf tissue. Phytochem. Bull. 19: 11-15.

Farris JS (1989). The retention index and the rescaled consistency index. Cladistics 5: 417-419.

Ferreira ME and Grattapaglia D (1998). Introdução ao Uso de Marcadores Moleculares em Análises Genéticas. EmbrapaCenargen, Brasília.

Hillis DM and Bull JJ (1993). An empirical test of bootstrapping as a method for assessing confidence in phylogenetic analysis. Syst. Biol. 42: 182-192.

Kluge AG and Farris KJS (1969). Quantitative phyletics and the evolution of anurans. Syst. Zool. 18: 1-32.

Kress WJ (1984). Systematics of Central American Heliconia (Heliconiaceae) with pendent inflorescenses. J. Arnold Arbor. 65: 483-485.

Kress WJ (1990). The diversity and distribution of Heliconia (Heliconiaceae) in Brazil. Acta Bot. Bras. 4: 159-167.

Kress WJ (1997). A synopsis of the genus Heliconia (Heliconiaceae) in Venezuela, with one new variety. Biollania (Edición Esp.) 6: 407-430.

Kress WJ and Specht CD (2006). The Evolutionary and biogeographic origin and diversification of the tropical monocot order Zingiberales. Aliso A 22: 619-630.

Kress WJ, Betancur J, Roesel CS and Echeverry BE (1993). Lista preliminar de las Heliconias de Colombia y cinco espécies nuevas. Caldasia 17: 183-197.

Kress WJ, Prince LM, Hahn WJ and Zimmer EA (2001). Unraveling the evolutionary radiation of the families of the Zingiberales using morphological and molecular evidence. Syst. Biol. 50: 926-944.

Kumar PP, Yau JCK and Goh CJ (1998). Genetic analyses of Heliconia species and cultivars with randomly amplified polymorphic DNA (RAPD) markers. J. Am. Soc. Hortic. Sci. 123: 91-97.

Li WH (1997). Molecular Evolution. Sinauer Associates Inc., Sunderland.

Nakai T (1941). Notulae ad plantas Asiae orientalis. J. Jpn. Bot. 17: 1-15.

Rohlf FJ (1993). NTSYS-pc: Numerical Taxonomy and Multivariate System. Version 2.9. Applied Biostatistics, New York. Schneider H (2003). Métodos de Análise Filogenética: Um Guia Prático. Editora Holos e Sociedade Brasileira de Genética, Ribeirão Preto.

Sokal RR and Rohlf FJ (1962). The comparison of dendrograms by objective methods. Taxon 11: 30-40.

Swofford DL (2002). PAUP: Phylogenetic Analysis Using Parsimony and Other Methods. v. 4. Sinauer Associates, Sunderland.

Williams JG, Kubelik AR, Livak KJ, Rafalski JA, et al. (1990). DNA polymorphisms amplified by arbitrary primers are useful as genetic markers. Nucleic Acids Res. 18: 6531-6535 